\title{
INTERNACIONALIZAÇÃO PRODUTIVA E AS RELAÇÕES BRASIL-ÁFRICA
}

Romênia Oliveira de Souza

Resumo: Com as exportações encabeçando o processo de crescimento da economia nacional e com o aumento dos investimentos diretos no exterior, países africanos se destacaram na implementação de ações da política externa brasileira. Analisou-se esse processo durante os anos Lula pela sua importância relativa para a economia nacional e pela pouca atenção concedida pela academia à referida questão. As estratégias adotadas pelo governo e pelas empresas brasileiras defendem a combinação de políticas ofensivas na busca de saldos comerciais crescentes e constitui-se em uma expansão baseada em commodities, impulsionada pelo interesse dos setores brasileiros em processo de internacionalização.

Palavras-chave: Política externa, internacionalização produtiva, Brasil, África.

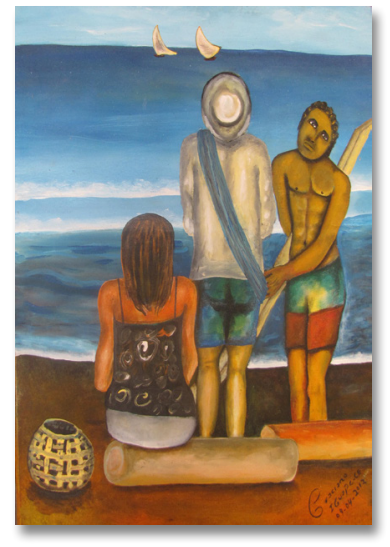

\section{Romênia Oliveira de}

\section{SouzA}

Mestra em

Desenvolvimento

Regional Sustentável

pela Universidade

Federal do Ceará (UFC).

Professora substituta

no Departamento

de Economia da

Universidade Regional

do Cariri (URCA).
PRODUCTIVE

INTERNATIONALIZATION AND BRAZIL-AFRICA RELATIONS

Abstract: With the exports heading the process of growth national economy and with the increase of the direct investments external, African countries stood out in the implementation of actions' Brazilian foreign policy. That process was analyzed during the years Lula by relative importance for the national economy and for the little attention granted by the academy to refer subject. The strategies adopted by the government and for the Brazilian companies, they defend the combination of offensive politics in the search of growing commercial balances and it's constituted in an expansion based in commodities, impelled by the interest of the Brazilian sections in internationalization process.

Keywords: Foreign policy, productive internationalization, Brazil, Africa. 


\section{INTRODUÇÃO}

O presente estudo investiga a internacionalização produtiva brasileira para os países africanos, durante os governos Lula. Em uma seção, apresentam-se o papel do Estado e seu alinhamento à dinâmica capitalista e às demandas dos grandes conglomerados nacionais na conjuntura de intenso crescimento do comércio exterior a partir de 2002, assim como a política externa de Lula, que compatibilizou os interesses dessas empresas com os do próprio governo. Em seguida, analisa-se o processo de maior internacionalização da produção do Brasil no período 2002-2010. Em outra seção, o foco do estudo se volta para as relações comerciais e para os investimentos diretos brasileiros na África.

Mesmo dispondo de informações limitadas, percebe-se a importância que os países africanos assumiram para o Brasil. Por fim, apresentam-se considerações sobre a situação das contas externas brasileiras e as vantagens de curto prazo da política implementada a partir de 2003. Trata-se de pesquisa descritivo-analítica, predominantemente qualitativa e utiliza-se de bibliografia especializada e de dados secundários provenientes de sites oficiais do governo federal.

\section{O PAPEL DO ESTADO E SEU ALINHAMENTO À DINÂMICA E ÀS DEMANDAS DAS GRANDES EMPRESAS NA CONJUNTURA DE INTENSO CRESCIMENTO DO COMÉRCIO EXTERIOR A PARTIR DE 2002}

\subsection{ESTRUTURA ECONÔMICA E DINÂMICA DO MODELO LIBERAL-PERIFÉRICO NO BRASIL.}

O modelo liberal-periférico se estruturou a partir de profundas mudanças, iniciadas nos anos 1990, em pelo menos cinco dimensões da organização econômica, social e política do país: a relação capital/trabalho; a relação entre as distintas frações do capital (mudanças nas relações intercapitalistas); a inserção internacional do país; a estrutura e o funcionamento do Estado; e as formas de representação política.

Com a abertura e desregulamentação dos mercados financeiros e com as privatizações, assistiu-se ao aprofundamento da 
financeirização da economia e a um movimento de centralização de capitais, ${ }^{1}$ através de fusões, aquisições e incorporações, ao mesmo tempo em que ocorria uma maior desnacionalização e internacionalização da economia (FILGUEIRAS et al, 2010). Para Carneiro (2002 apud FILGUEIRAS et al, 2010, p. 43), em decorrência desse fato, assistiu-se também "a um processo de desindustrialização, com redução da participação relativa da indústria na economia nacional e especialização regressiva". Com a quebra de monopólios estatais em vários setores e com as privatizações o Estado reduziu sua participação nas atividades diretamente produtivas fortalecendo grupos privados nacionais ou não (FILGUEIRAS et al, 2010).

Ou seja, os papéis de Estado condutor, regulamentador e produtor foram modificados, enquanto que o de Estado financiador, captador e repassador de poupanças, ainda não foi desmantelado. Essas mudanças estão intrinsecamente relacionadas à dinâmica de acumulação e de concentração de capital pelas quais passou o Brasil (GREMAUD; VASCONCELLOS; TONETO JR., 2011). O padrão de acumulação capitalista brasileiro, inaugurado com as privatizações (uma tentativa de formar grandes conglomerados pela associação de grupos), e a liberalização comercial dos anos 1990 estão baseados na formação de conglomerados privados nacionais e estrangeiros, fomentados pelos fundos públicos (TAUTZ et al, 2010).

Entre 1989-1995, os grupos nacionais ampliaram-se e concentraram-se nos setores de siderurgia e petroquímica, em que a participação estatal foi contraída pelo capital nacional (MIRANDA; TAVARES, 1999). No período 1995-2002, surgiram redes de proprietários baseadas em relações societárias² conectadas entre

\footnotetext{
1 A centralização do capital resulta de luta concorrencial em busca do barateamento de mercadorias, dependendo, portanto, do aumento da escala de produção e da produtividade (KON, 1999).

2 As sociedades anônimas, ou de capital aberto, propiciam enorme expansão na escala produtiva que não seria possível individualmente. O capital privado toma forma de capital social e as empresas, consequentemente, tornam-se empresas sociais. O fornecedor de capital fica com responsabilidades limitadas de acordo com seu investimento inicial, mas pode votar nos assuntos decisivos da empresa (KON, 1999).
} 
si, configurando oligopólios. Empresas tradicionais (Gerdau, Andrade Gutierrez, Camargo Correa, Odebrecht, Votorantim, Bradesco/Vale) valeram-se das liberalizações e privatizações e assumiram posições nos referidos setores, bem como na telefonia. Também passaram a integrar essas redes as estatais, o BNDESPar e a Eletrobrás, além dos fundos de pensões de funcionários de empresas públicas.

O BNDES, em especial, tem atuado na internacionalização de empresas destes setores na América do Sul e na África, reproduzindo nessas regiões o modelo de especialização produtiva e de desapropriação das populações e territórios. A perspectiva de integração regional adotada está voltada para a liberalização do comércio e dos investimentos, aprofundando o modelo de inserção competitiva. A diferença do governo Lula em relação ao período anterior está na suposta defesa de grupos nacionais, pelo Estado, bem como da escolha dos 'eleitos' (TAUTZ et al, 2010).

De modo geral, não houve alterações na correlação de forças entre capital e trabalho. Entretanto, recuperou-se o emprego, reduziu-se o desemprego e houve melhoras no salário real e no salário mínimo, resultantes do crescimento econômico ocorrido a partir de 2006 (FILGUEIRAS et al, 2010). O gráfico 1 reflete esse crescimento no período 2002-2010.

\section{Gráfico 1 - Crescimento do PIB (R\$ milhões) brasileiro no período 2002-2010}

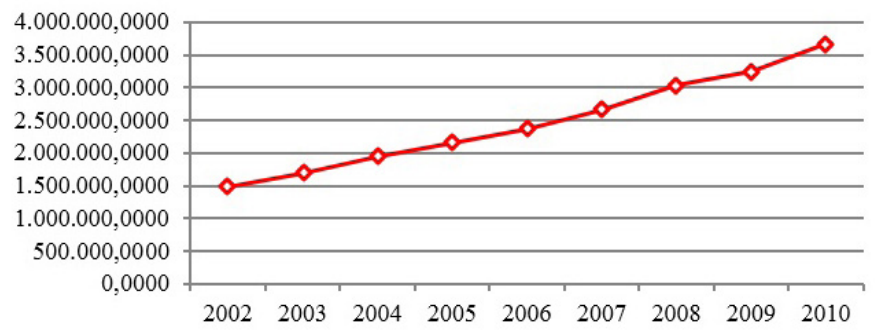

Fonte: IBGE/SCN 2000 Anual

Mesmo a política internacional do país (proativa para muitos), responde à demanda de multinacionais brasileiras em termos da criação de ambientes externos favoráveis para seus investimentos. 
Embora se privilegie empresas de capital nacional, não há qualquer garantia de que essas mesmas não venham a ser controladas por empresas de capital estrangeiro. Também a política industrial que apresenta projeções de maiores investimentos em inovação e tecnologia, capazes de favorecer a exportação de produtos de maior valor agregado, na realidade despeja recursos no setor de commodities (TAUTZ et al, 2010).

\subsection{A POLÍTICA EXTERNA DOS GOVERNOS LULA.}

As relações internacionais dos governos Lula foram dotadas de três dimensões diplomáticas: econômica, política e social. A primeira dimensão se referiu à necessidade de manter abertos os canais de negociação com os países mais desenvolvidos, obtendo investimentos e tecnologias, negociando a dívida externa e sinalizando o desejo do governo em cumprir os compromissos internacionais, sem nenhuma ruptura brusca ou quebra do modelo macroeconômico (VIZENTINI, 2008). Significou que, para conquistar a credibilidade e garantir a governabilidade do país, Lula: honrou o acordo com o FMI e sua renovação; preservou a diretoria do Banco Central, intimamente relacionada ao sistema financeiro globalizado; escolheu uma equipe econômica comprometida com a estabilidade econômica e com o ajuste fiscal (GREMAUD; VASCONCELLOS; TONETO JR., 2011).

A promoção dos negócios e o aprofundamento das relações comerciais entre as distintas economias, com a manutenção do grau de abertura comercial e da reestruturação produtiva ulterior promoveu ao longo dos governos Lula a elevação da dependência do mercado externo como centro dinâmico da economia brasileira. Isso acentuou o processo de reprimarização das exportações e elevou a vulnerabilidade externa estrutural da economia brasileira (CARCANHOLO, 2010). Por outro lado, a diplomacia política representou a reafirmação dos interesses nacionais e um verdadeiro protagonismo nas relações internacionais, com a intenção real de desenvolver uma diplomacia ativa e afirmativa. Foi promovida a adoção de políticas afirmativas sem quotas, acréscimo do número de diplomatas, abertura de embaixadas na África e na Ásia e maior abertura da diplomacia à sociedade civil e acadêmica. 
O projeto social interno do governo Lula (com impactos internacionais) foi ao encontro da agenda que busca corrigir as distorções criadas pela globalização centrada apenas em comércio e investimentos livres. A campanha de combate à fome foi o elemento simbólico da construção de um modelo socioeconômico alternativo, respondendo a crise da globalização neoliberal (VIZENTINI, 2008).

O governo brasileiro superou a passividade do anterior e buscou alianças fora do hemisfério para ampliar seu poder de influência no âmbito internacional a partir da mencionada postura ativa e pragmática. A integração sul-americana se realiza em três níveis: o comercial e de investimentos, relativamente consolidado com o MERCOSUL; o operacional de construção de infraestrutura de transportes, comunicações e energia; e o nível político (VIZENTINI, 2008). O Brasil também liderou o MERCOSUL contra a tentativa de o governo estadunidense impor uma agenda unilateral para a Área de Livre Comércio das Américas (SOUZA, 2008);

As relações Norte-Sul ganharam um novo enfoque: ao contrariar alguns desígnios da potência hegemônica - recusando-se em respaldar ações contra o Iraque sem que os inspetores da ONU concluíssem seu trabalho e aprovassem uma invasão - e ao ressaltar sua autonomia, a diplomacia brasileira criou uma razoável margem de manobra. Chamou atenção para suas reinvindicações socioeconômicas e para obras de infraestrutura com os vizinhos (VIZENTINI, 2008). O presidente Lula também reivindicou a queda das barreiras alfandegárias ${ }^{3}$ e dos subsídios agrícolas ${ }^{4}$ (RODRIGUES; VARGAS; SILVA, 2009).

As estratégias de cooperação Sul-Sul tiveram ações focadas em pontos comuns sem a criação de uma frente anti-hegemônica ou anti OCDE. O primeiro passo foi a constituição do IBAS ou G-3

3 Alguns produtos brasileiros estão sujeitos a quotas de exportações. Aqueles que ultrapassarem tais limites pagam tarifas exorbitantes. Nos EUA: suco de laranja, etanol, açúcar, carne de frango, suína e bovina, fumo, frutas tropicais, vegetais e produtos siderúrgicos. Na União Europeia: carne suína e bovina, frango, milho, açúcar e suco de laranja. No Japão: amendoim descascado e frutas tropicais. E no Canadá: aves, particularmente o frango (MAIA, 2011).

4 Em 2003, a União Europeia estabeleceu subsídios para a produção do setor bovino (100\%) e de aves e caprinos (50\%). Em 2007, os EUA aprovaram uma lei que proporcionou até 2012 subsídios agrícolas no valor de US\$284 bilhões (MAIA, 2011). 
(Fórum de cooperação entre Índia, Brasil e África do Sul), procurando gerar a cooperação trilateral, a liberalização comercial recíproca e a unificação e fortalecimento de posições nos foros multilaterais. Uma contribuição à construção de um sistema mundial multipolar, sem hegemonias e regido por organizações multilaterais (VIZENTINI, 2008).

Outras iniciativas importantes foram as visitas de Lula aos países árabes do Oriente Médio e a aproximação com a África para aproveitar lacunas existentes no sistema internacional, ocupando espaços extremamente importantes para ampliar exportações de bens e serviços e expandir a ação de empresas brasileiras e a influência internacional do país. A solidariedade ativa também foi importante, com os projetos na área social e de saúde, além da atuação conjunta nos organismos internacionais, como o G-20. Portanto, o protagonismo brasileiro junto ao Terceiro Mundo e a diversificação dos vínculos com o Primeiro, intensifica sua campanha para obtenção de um assento permanente no Conselho de Segurança da ONU (VIZENTINI, 2008), onde o Brasil assumiu a posição de líder na missão de paz no Haiti.

As ações de diversificação de parcerias fizeram também parte da aposta central na potencialização do comércio exterior brasileiro com vistas à produção de saldos comerciais superavitários que evitassem o aprofundamento da dependência do país a capitais estrangeiros de curto prazo. Ou seja, objetivou-se acabar com a dívida externa e com a vulnerabilidade externa do país herdada do governo FHC (FIGUEIRA, 2011).

Entretanto, as reformas estruturais pró-mercado (incluindo liberalização comercial, financeira e produtiva), do governo anterior, não apenas são mantidas como aprofundadas em seu governo. No que se refere à liberalização financeira, foram aprovadas a unificação do mercado cambial permitindo a não discriminação entre exportadores e importadores; e a extinção da conta de não residentes visando não limitar pessoas físicas e jurídicas na conversão de reais em dólares, facilitando a saída de recursos.

A expansão dos prazos para a cobertura cambial das exportações significava a manutenção de 30\% de receitas em dólares no exterior, apontando para o fim da obrigação de convertê-las para 
moeda nacional, ao mesmo tempo em que lhes permite atuar no mercado especulativo de câmbio no interim entre o recebimento dos dólares e sua eventual transformação em reais. O governo também criou uma medida provisória concedendo incentivos fiscais aos investidores estrangeiros para aquisição de títulos da dívida pública interna (CARCANHOLO, 2010).

Portanto, a questão central do governo Lula foi ampliar os superávits no comércio exterior e acumular saldos e reservas internacionais que protegeriam o país dos movimentos de capitais em direção ao exterior. Implicava uma espécie de dualidade da estrutura exportadora brasileira: manufaturas para o continente americano e produtos intensivos em recursos ambientais (agrícolas e minerais) para a Europa e a Ásia. Como no interior do complexo industrial brasileiro também se importa muito, a possibilidade de ampliar rapidamente os saldos comerciais se apoiava na perspectiva do incremento das exportações agrícolas e minerais no curto prazo. Deve-se considerar ainda a transnacionalização de algumas empresas brasileiras, e sua expansão para espaços regionais e para a África (MINEIRO, 2010).

\section{A INTERNACIONALIZAÇÃO DA PRODUÇÃO BRASILEIRA}

A internacionalização produtiva é considerada estratégia-chave, de sobrevivência interna e externa, para as empresas no mundo globalizado (SILVA, 2003). A escolha em internacionalizar sua produção via exportação e/ou investimentos diretos depende de fatores locacionais específicos ${ }^{5}$ e referem-se tanto ao país de origem da empresa quanto ao país receptor (BAUMANN; CANUTO; GONÇALVES, 2004).

O gráfico 2 mostra a composição das exportações brasileiras totais no período 2002-2010. Percebe-se o crescimento das

5 Menciona-se: dotação de fatores, tamanho do mercado, potencial de crescimento do mercado, clima de investimento, custos de transportes, barreiras comerciais, disponibilidade de infraestrutura, economias de escala, aparato regulatório (DUNNING, 1988 apud BAUMANN; CANUTO; GONÇALVES, 2004) e ciclo de vida do produto que se desenrola internacionalmente (KON, 1999). 
exportações ao longo dos anos, tendo uma redução de mais de US\$ 44 bilhões de 2008 para 2009, em razão da crise. Em 2010, o valor exportado volta a crescer (mais de US $\$ 48$ bilhões), atingindo o patamar superior a US\$201 bilhões, o mais alto do período. É nítida a importância relativa dos produtos industrializados manufaturados na pauta de exportações brasileira. Os produtos básicos vêm em seguida. O fato relevante é a reversão de posições dos produtos básicos e manufaturados no ano 2010, onde os primeiros respondem por $44,6 \%$ das exportações totais e os manufaturados por 39,4\%. Em 2009, os manufaturados respondiam por 44\%, enquanto os básicos 40,5\%.

\section{Gráfico 2 - Composição das exportações brasileiras totais no período 2002-2010}

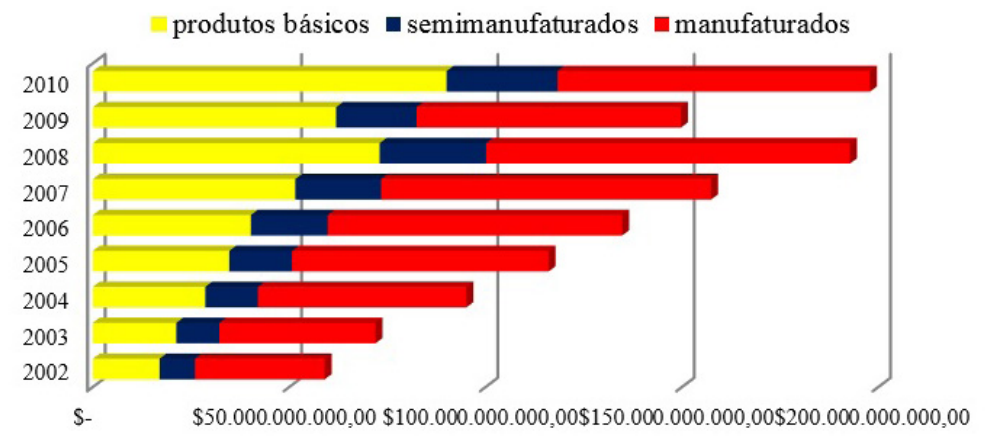

Fonte: Exportações brasileiras totais por fator agregado. Secex/MDIC (2011).

Vários fatores explicam a perda de importância dos produtos agrícolas no comércio internacional ao longo das décadas. E tratando especificamente dos anos Lula, o primeiro mandato assistiu a uma quase estagnação das vendas agrícolas ao exterior, refletida no fato de que o valor exportado em 2006 encontrava-se praticamente no mesmo patamar de 2003. ${ }^{6}$ Em 2008, quando a economia mundial ainda estava aquecida, as vendas agrícolas externas voltaram a crescer em valor. As vendas do agronegócio

6 Os valores exportados de produtos agrícolas, e não de produtos básicos, que estavam praticamente iguais em 2003 e 2006. 
brasileiro estão fortemente concentradas nos itens de soja e carne. Seguidas por produtos do complexo sucroalcooleiro; vendas de café, tabaco, do complexo de cereais e de frutas; comércio de fibras e lã e outros produtos de origem vegetal (FEIJÓ, 2011). ${ }^{7}$

O desempenho das importações também se mostrou igualmente notável, embora o ritmo de crescimento seja menos brilhante. Conjuntamente, as evidências disponíveis confirmam o padrão de tipo Heckscher-Ohlin para o comércio internacional brasileiro (BAUMANN; CANUTO; GONÇALVES, 2004). Entretanto, a relevância do custo relativo dos fatores na determinação da estrutura de comércio brasileiro no período recente deve ser relativizada, levando-se em conta as alterações na política de comércio nacional, a intensidade relativa em recursos naturais e os efeitos das barreiras comerciais externas (NONNENBERG, 1995 apud BAUMANN; CANUTO; GONÇALVES, 2004).

Quanto aos investimentos diretos no exterior, o Brasil tem aplicado capitais para criar empresas filiais de exportadoras e de bancos brasileiros. O total dos investimentos brasileiros no exterior cresceu de 2005 a 2009, e deveu-se à maior presença das empresas que aproveitaram a apreciação do real, particularmente com relação ao dólar, para comprar ativos externos. Em julho de 2010 o total de investimentos atingiu US\$ 514 bilhões. O que contribuiu bastante para essa elevação foi o aumento dos ativos de reservas externas do Banco Central brasileiro (O ESTADO DE SÃO PAULO, 2010 apud MAIA, 2011). O gráfico 3 mostra a evolução dos investimentos diretos brasileiros no exterior entre 20022010 em milhões de dólares americanos.

7 Os principais clientes do agronegócio brasileiro são: o bloco europeu, com destaque para Alemanha e Países Baixos, caindo sua participação na carteira de clientes no século XXI; e China (importa a soja brasileira); a Ásia com suas exclusões; o continente africano; e a Rússia (compradora de carne) (FEIJÓ, 2010). 


\section{Gráfico 3 - Investimentos diretos brasileiros no exterior entre 2002-2010.}

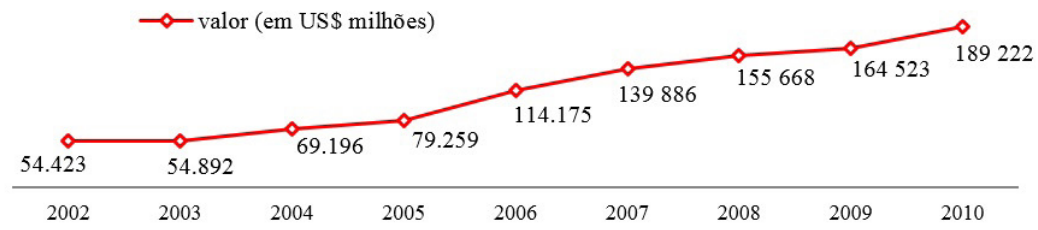

Fontes: Declarações do CBE do Banco Central do Brasil (2006; 2010).

Os principais motivos da expansão de empresas brasileiras no exterior foram: medidas contra o protecionismo externo (a exemplo de indústrias siderúrgicas implantadas nos EUA para vencer a política americana de proteção às ultrapassadas produtoras daquele país); o custo Brasil (apreciação do real, elevadas taxa de juros e pesada carga tributária); sistema de transportes deficiente e caro; burocracia brasileira. Como consequência, foram gerados empregos e impostos no exterior. Também a maior proximidade do comprador dá à empresa brasileira condições de fornecimento mais rápido ao cliente. Assim como ganhos de escala, decorrentes do aumento da produção, onde a empresa não fica dependente de um só mercado (MAIA, 2011).

No que diz respeito à reestruturação da indústria brasileira, a abertura comercial e o regime macroeconômico levaram a adaptações (de ordem organizacional ou tecnológica) por parte das empresas industriais: "concentração seletiva de atividades nas áreas de maior competência; redução dos níveis de integração vertical com ampliação do conteúdo importado de partes e componentes; reorganização e compactação dos processos e layouts de plantas; e redução das hierarquias e níveis organizativos das empresas" (MIRANDA, 2001, p. 18 apud SILVA, 2003). Os grupos brasileiros que atuavam tradicionalmente nos setores de bens de capital, eletrônica profissional, entretenimento e construção civil pesada, ou que compunham conglomerados financeiros, foram os que passaram por redefinições mais drásticas de suas estratégias, devido à nova inserção internacional do Brasil ou aos processos 
de privatizações e concessão de serviços das estatais (MIRANDA; TAVARES, 1999).

Distinguem-se três estratégias de inserção no período recente. A primeira é a daqueles que resistem em seus corebusiness originários e usam as privatizações para reforçá-los sendo bem-sucedidos: grupo Gerdau (de siderurgia); grupo Votorantim que conserva seus setores originários e avança em consórcios com o Bradesco e a Camargo Correia pelo setor de energia elétrica e gás; e grupo Itaú S.A. na área financeira.

A segunda é identificada com aqueles que reduzem sua conglomeração ou reforçam sua especialização em commodities e aqueles que tentam aproveitar os consórcios de privatizações para reforçar suas especializações em telecomunicações e/ou multimídia, mas perdem ou saem como sócios minoritários das empresas privatizadas. A terceira estratégia é identificada com um único conglomerado diversificado com participações cruzadas das diversas empresas recém-adquiridas: CSN na Light, Vale na CSN, etc. (MIRANDA; TAVARES, 1999).

Ou seja, as grandes corporações nacionais tentaram se inserir em nichos de mercados nos quais conseguiam ser mais competitivas, e se voltaram para os produtos intensivos em recursos naturais, de baixo conteúdo tecnológico e de menor valor agregado. O estabelecimento de subsidiárias brasileiras no exterior complementa suas respectivas atividades de exportações. Muitas vezes o investimento direto ocorre por meio de compras ou associações com grupos locais (SILVA, 2003).

Dados da UNCTAD relativos a 2004 revelaram as maiores multinacionais brasileiras nos setores não financeiros e de manufaturados segundo a quantidade de países onde estão presentes, conforme apresentado no quadro a seguir. 


\section{Quadro 1 - Companhias brasileiras com maior quantidade de filiais em outros países em 2004}

\begin{tabular}{|l|c|}
\hline Companhias & $\begin{array}{c}\text { Quantid./ } \\
\text { países }\end{array}$ \\
\hline Odebrecht & 14 \\
\hline Tomra Latasa & 7 \\
\hline Petrobras & 6 \\
\hline WEG & 5 \\
\hline Vale & 4 \\
\hline Tupy Fundições, Andrade Gutierrez, AmBev, Altus. & 3 cada uma \\
\hline CSN, Gerdau, Tigre, São Paulo Alpargatas. & 2 cada uma \\
\hline $\begin{array}{l}\text { Embraer, Marcopolo, Politec, Teka, IBF, Forjas } \\
\text { Taurus, Renner Hermann, Sisalana, Seisa Clerman } \\
\text { Empreendimentos, Embratel. }\end{array}$ & 1 cada uma \\
\hline
\end{tabular}

Fonte: O Estado de São Paulo, 2006 apud Maia, 2011.

O grupo Votorantim instalou escritórios no exterior com vistas a estar mais próxima de clientes e evitar intermediação por tradings. A Gerdau adquiriu usinas siderúrgicas com o intuito de fortalecer o seu mercado pela proximidade com os consumidores e utilização de insumos fornecidos localmente. Além de ultrapassar as barreiras comerciais em razão do protecionismo de determinados países. A Odebrecht adquiriu empresas do setor da construção civil e realizou projetos com governos de vários países, objetivando entrar nos mercados. A Andrade Gutierrez contraiu empresas já existentes (como em Guiné-Bissau, por exemplo) e em parceria com a Odebrecht (em Portugal) visando entrar no mercado da União Europeia. E a Vale (joint venture com a canadense Iamgold Corporation) para exploração de ouro, além de fábricas localizadas e escritórios.

Os escassos dados disponíveis sobre as empresas brasileiras que investiram no exterior mostram que se trata de um número reduzido de empresas cujas atividades ainda estão atreladas ao comércio de exportação (SILVA, 2003). O governo Lula promoveu o retorno do Estado interventor para reforçar o capital financeiro 
bancário e produtivo e fortalecer os grandes grupos econômicos nacionais (privados ou não). Na crise mundial recente, a intervenção se deu diretamente no processo de associação da Sadia e Perdigão através do BNDES, e na compra de parte do Banco Votorantim através do Banco do Brasil. Na área de infraestrutura e petroquímica, grupos nacionais associados ao Estado implementam megaempreendimentos para exploração futura dos serviços que daí derivarão (FILGUEIRAS et al, 2010).

Entretanto e contraditoriamente, o crescimento das multinacionais brasileiras no exterior já está criando problemas para algumas delas. Em 2006, a Petrobras e o Grupo Brasileiro EBX tiveram suas instalações tomadas pelas tropas do exército boliviano. Em 2008, o presidente do Paraguai questionou, de forma preocupante, o sistema de remuneração da energia elétrica da Usina de Itaipu, fornecida pelo Paraguai ao Brasil. Neste mesmo ano, o presidente do Equador expulsou a Construtora Odebrecht de seu país e ameaçou tomar medida idêntica com relação à Petrobras (MAIA, 2011).

\section{A ÁFRICA PARA O BRASIL}

As relações estabelecidas pelos países africanos com o Brasil foram peculiares: em um primeiro momento ficou restrita a ações isoladas por parte do governo brasileiro, e a partir de 1960, com o apoio à descolonização africana.8 Isso porque, enquanto colônias, suas relações exteriores só aconteceriam conforme os interesses das metrópoles (VIZENTINI, 2008). A partir de 2003, a aproximação do Brasil com o continente se consolidou pela coordenação de questões da agenda internacional de interesse mútuo e pela busca da cooperação econômica (MRE, 2010). O quadro 2 resume as principais ações empreendidas a partir de 1960.

8 A maioria dos países se emancipou nos anos 1950-60. Confrontados com os problemas da descolonização, particularmente quanto à orientação políticoeconômica a seguir, esses jovens Estados associaram-se em nível continental: a Organização da Unidade Africana. Esta organização aprovou a manutenção das fronteiras herdadas do colonialismo, em face da absoluta falta de outros parâmetros para a delimitação das fronteiras dos novos estados (VIZENTINI, 2007). 
O Brasil mantém relações estreitas com quarenta países: África do Sul, Angola, Argélia, Benin, Botsuana, Burkina Faso, Burundi, Cabo Verde, Camarões, Chade, Congo e Costa do Marfim. Egito, Gabão, Gâmbia, Gana, Guiné, Guiné Equatorial, Guiné-Bissau, Libéria e Líbia. Malaui, Mali, Marrocos, Mauritânia, Moçambique, Namíbia. Níger, Nigéria, República Democrática do Congo, República do Congo, São Tomé e Príncipe, Senegal, Serra Leoa. Somália, Sudão, Tanzânia, Togo, Tunísia e Zâmbia (MRE, 2010). Tomado em conjunto, é o quarto maior parceiro comercial do país e sede de investimentos brasileiros no exterior em diversos setores.

\section{Quadro 2 - Síntese de relações econômicas internacionais entre o Brasil e o bloco África.}

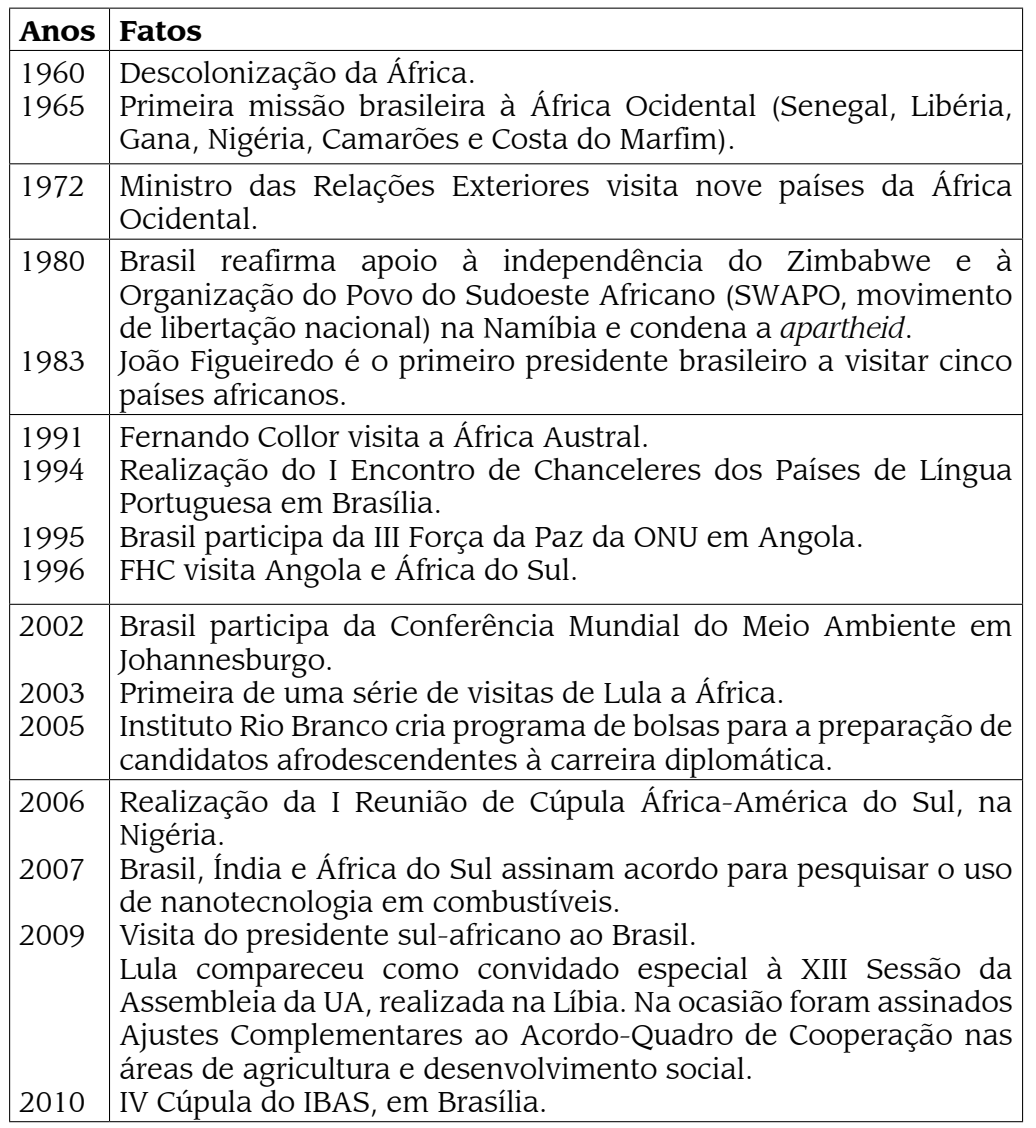

Fonte: Vizentini, 2008; MRE, 2010. 


\subsection{COMPOSIÇÃO DOS FLUXOS COMERCIAIS BRASIL- BLOCO ÁFRICA DURANTE OS GOVERNOS LULA}

O gráfico 4 representa o intercâmbio comercial brasileiro com o bloco África no período 2002-2010 e os respectivos saldos da balança comercial brasileira para o continente (exclusive Oriente Médio).

\section{Gráfico 4 - Balança comercial brasileira com o bloco África (exclusive Oriente Médio) a preços FOB}

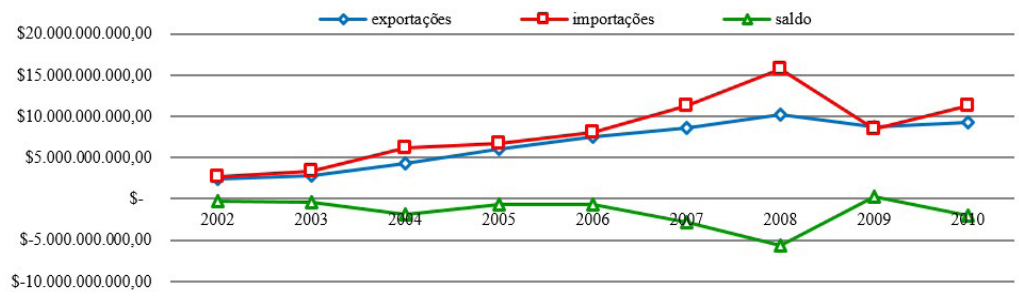

Fonte: Intercâmbio comercial brasileiro com o bloco África, exclusive Oriente Médio. Secex/MDIC (2011).

Neste período, o saldo comercial foi deficitário, exceto em 2009 com um superávit superior a US\$ 226 milhões. Apesar dos sucessivos déficits, o intercâmbio com o bloco África cresceu consideravelmente no período analisado em virtude das políticas ${ }^{9}$ adotadas nos anos Lula. Também foi importante a conjuntura econômica internacional (positiva até meados de 2008) e o peso dos países emergentes no cenário global.

A participação percentual das exportações brasileiras para a África em relação às exportações brasileiras totais foi de: 3,91\% (2002 e 2003), 4,39\% (2004), 5,05\% (2005), 5,41\% (2006), 5,34\% (2007), 5,14\% (2008), 5,68\% (2009) e 4,59\% (2010). O continente cresceu em importância, como comprador de produtos brasileiros, tendo sofrido uma pequena redução em 2010. O destaque para o

9 Além da política externa, citam-se: o acordo para evitar a dupla tributação (em 2003) e o acordo de cooperação aduaneira (em 2008) com a África do Sul e o memorando de atendimento interinstitucional entre o MDIC e seu homólogo sul-africano (2009); o acordo de preferências comerciais (SACU) com os países do sul da África; e um acordo comercial com a Argélia em 2006 (MRE, 2011). 
ano de 2009, apesar de não registrar o maior fluxo de intercâmbio, se deve pelo saldo positivo apresentado, provavelmente, em razão das economias africanas terem sido menos afetadas pela crise financeira internacional que a economia brasileira.

Já a participação das importações provenientes da África em relação às importações totais do Brasil foi de: 5,66\% (2002), 6,81\% (2003), 9,84\% (2004), 9,04\% (2005), 8,88\% (2006), 9,41\% (2007), 9,11\% (2008), 6,63\% (2009) e 6,22\% (2010). De 2006 a 2008 os déficits comerciais se intensificaram. E de 2008 para 2009, as importações sofreram uma queda brusca. Em 2010, seu valor cresceu em relação ao ano anterior, mas manteve-se um pouco abaixo do registrado em 2007, quando as economias ainda não enfrentavam a crise de 2008. O crescimento das importações brasileiras provenientes do bloco África causa alguns efeitos diretos e indiretos sobre as economias em questão: ao mesmo tempo em que parte das necessidades brasileiras é suprida por esses produtos, geram-se divisas e rendas naqueles países que também consomem produtos nacionais.

O gráfico 5 mostra o padrão das exportações brasileiras para o bloco África, onde há o predomínio de produtos manufaturados, imediatamente seguidos pelos básicos. E com menor quantidade de vendas, os semimanufaturados. De 2002 a 2007 a relação vendas de manufaturados > básicos > semimanufaturados se manteve relativamente constante. De 2008 a 2010 as vendas de produtos básicos cresceram (de pouco mais de US\$2,1 bilhões para mais de US\$ 2,9 bilhões), enquanto os manufaturados sofreram reduções (de mais de US\$ 5 bilhões para US\$ 4,3 bilhões) e os semimanufaturados cresceram (de US\$ 1,4 bilhão para US\$1,9 bilhão). 


\section{Gráfico 5 - Composição das exportações brasileiras para o bloco África entre 2002-2010}

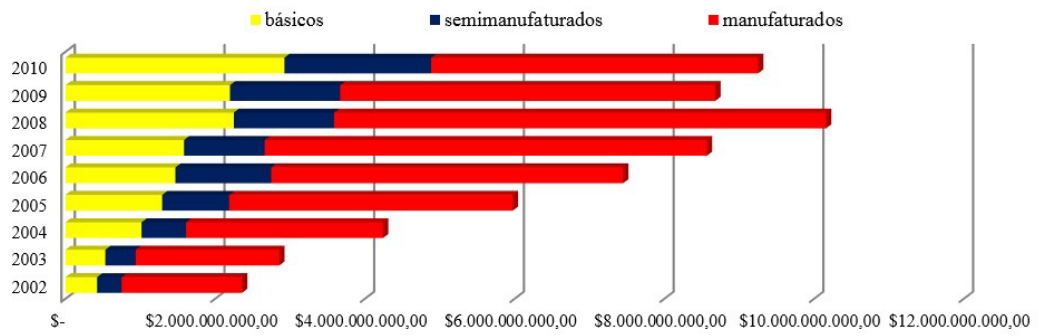

Fonte: Exportações brasileiras para o bloco África, exclusive Oriente Médio, por fator agregado. Secex/MDIC (2011).

Em documento do SECEX/MDIC (2009) sobre o intercâmbio comercial brasileiro em 2006, são citados seis países africanos e os principais produtos intercambiados. São eles: África do Sul, Angola, Argélia, Marrocos, Moçambique e Nigéria.

A África do Sul importou US\$907.902.000 e exportou US\$ 37.265.881.000 para o Brasil. O intercâmbio envolveu: máquinas e motores; veículos automotores e suas partes; materiais elétricos e eletroeletrônicos; produtos químicos; metalúrgicos; têxteis; plásticos; metais não ferrosos; metais e pedras preciosas; papel e celulose; e aviões. Angola importou US\$ 837.779.000 e exportou US\$ 459.500.000. Seu intercâmbio com o Brasil envolveu: veículos automotores e peças de reposição; produtos metalúrgicos; químicos; têxteis; ferramentas e talheres; e carnes de aves. A Argélia importou US\$ 456.723.000 e exportou US\$1.970.702.000. O intercâmbio envolveu: máquinas e motores; produtos metalúrgicos; veículos automotores e suas partes; materiais elétricos e eletroeletrônicos; plásticos; produtos químicos; instrumentos de precisão; produtos farmacêuticos; açúcar e álcool; madeiras, cortiças e obras de trançarias; papel e celulose; metais não ferrosos; soja (grãos, óleo e farelo).

Ainda em 2006, o Marrocos importou US\$ 391.576.000 e exportou US\$ 331.297.000. As trocas envolveram: materiais elétricos e eletroeletrônicos; máquinas e motores; têxteis; veículos automotores e suas partes; produtos metalúrgicos; plásticos e derivados; produtos químicos; metais não ferrosos; madeiras, cortiças e 
obras de trançarias; papel e celulose. Moçambique importou US\$ 35.212.000 e exportou US\$15.980 para o Brasil. O intercâmbio se dá nos setores de: veículos automotores e suas partes; máquinas e motores; cereais em grão; materiais elétricos e eletroeletrônicos; produtos metalúrgicos, minerais, químicos e têxteis.

Com a Nigéria, o intercâmbio envolve: aparelhos transmissores com receptor incorporado (incluem celulares); polietileno e polipropileno; tubos utilizados em oleodutos e gasodutos; pneus para ônibus e caminhões; unidades de entrada, saída e memória; ácido glutâmico e seus sais; máquinas e aparelhos mecânicos; instrumentos e aparelhos hidráulicos ou pneumáticos, para regulação e controle. Partes de bombas de ar ou de vácuo, de compressores de ar ou de outros gases e de ventiladores; fios de cobre; papéis e cartões; ladrilhos, placas (lajes), cubos, pastilhas. Medicamentos; geradores e motores elétricos; torneiras e válvulas; tubos de perfuração. A Nigéria importou, em 2006, US\$1.373.624.000 e exportou US\$ 3.918.296.000 (SECEX/MDIC, 2009).

\subsection{EMPRESAS BRASILEIRAS NA ÁFRICA DURANTE OS GOVERNOS LULA}

A participação da África nos fluxos mundiais de investimentos externos diretos vem crescendo em importância, conforme indicam dados da UNCTAD (apud IGLESIAS; COSTA, 2011): 1,4\% em 1990; 0,8\% em 2000; 2,9\% em 2004; e 5,1\% em 2010. A participação dos países emergentes nesses investimentos realizados também cresceu: de 18\% entre 1995-1999 para 21\% entre 2000-2008 (WIR, 2001 apud IGLESIAS; COSTA, 2011). As vantagens desses investimentos para os países africanos estão no fato de que são intensivos em mão-de-obra e as tecnologias usadas pelas transnacionais são facilmente adequadas àqueles com mesmo nível de desenvolvimento, contribuindo para um upgrade tecnológico. Os fluxos de investimentos globais se concentram fortemente no setor primário: quinze países são exportadores da indústria petrolífera e a maioria está no norte da África (WIR, 2001 apud IGLESIAS; COSTA, 2011). 
Empresas brasileiras estão realizando investimentos diretos no continente africano nas áreas relativas a cimento, mineração, finanças, agricultura e petróleo: CSN (em Moçambique e África do Sul), Banco do Brasil (Moçambique, Angola, Cabo Verde, Líbia, Argélia e Marrocos), Votorantim (Tunísia, Egito, Moçambique e África do Sul). Petrobras (na Tanzânia, Angola, Nigéria, Líbia e Namíbia), Vale (Zâmbia, Moçambique, Angola, Libéria, Congo e Gabão), Odebrecht (Moçambique, Angola, Guiné Equatorial, Gana, Libéria, Guiné e Líbia), Camargo Correa (Moçambique e Angola) e Conacri (Guiné) (MAIA, 2011). Esses investimentos exploram oportunidades de mercados nacionais ou regionais, extraem recursos naturais e constroem grandes obras públicas (que vão desde estradas a usinas de energia) (MRE, 2011). A Odebrecht é a transnacional brasileira mais diversificada. Seus investimentos se dão em setor imobiliário, construção, bioenergia, mineração, agronegócio e energia (IGLESIAS; COSTA, 2011).

Quanto à exploração de recursos naturais, a Vale, dentre seus projetos, venceu a concorrência internacional para explorar um complexo carbonífero em Moçambique (investimentos estimados em mais de US\$ 4,5 bilhões) e explorará 51\% das operações das ricas jazidas de ferro da Guiné (direito comprado por US\$2,5 bilhões). A Petrobras, atuante em diversos países, tem na Nigéria seu principal parceiro: vem deste país parte considerável do petróleo importado pelo Brasil. Os poços Agbami e Akpo fazem da unidade nigeriana uma das maiores produtoras do Sistema Petrobras fora do Brasil, no curto e no médio prazo (MRE, 2011).

As razões para os relativamente baixos investimentos diretos brasileiros realizados na África, em comparação com a América Latina, se devem: ao menor grau de desenvolvimento relativo da África; ao desconhecimento do ambiente de negócios e dos riscos maiores inerentes às débeis instituições e às restrições do ambiente de negócios. Assim, as transnacionais brasileiras citam que os principais problemas encontrados se devem ao ambiente institucional e de negócios. Mesmo com tais problemas, ainda existem motivadores para seguir investindo. Dentre os problemas de ordem institucional cita-se: o receio de perder uma concorrência por causa de regras pouco claras e restritivas. Dentre os problemas 
relacionados ao ambiente de negócio estão: o grau relativamente baixo de desenvolvimento que dificulta o aproveitamento de oportunidades; a baixa qualificação da mão-de-obra; a energia e a mineração têm fornecedores estrangeiros de equipamentos e materiais e a mão-de-obra especializada é estrangeira.

As vantagens são: os riscos inerentes às regras claras são incorporados aos custos do investimento; há abundância de recursos; o baixo grau de desenvolvimento pode representar uma oportunidade para empresas com corebussiness diversificado e com capacidade gerencial e de mobilização de conhecimentos (IGLESIAS; COSTA, 2011).

A tendência à internacionalização de empresas brasileiras em direção à África reproduz fora, de forma mais dramática, os impactos socioambientais que produzem no interior do Brasil. Na percepção de muitos movimentos e organismos sociais africanos, já está ficando claro que o BNDES vem substituindo o BID e o Banco Mundial em financiamentos a projetos com graves impactos sociais e ambientais em seus territórios e que implicam também endividamento dos seus Estados (TAUTZ et al, 2010).

\section{CONSIDERAÇÕES FINAIS}

As contas externas brasileiras melhoraram no período 20022006 devido: a alta no ciclo de liquidez internacional (em razão da redução das taxas internacionais de juros, proporcionando o crescimento da economia mundial e reduzindo o risco-país); intenso crescimento da economia chinesa (importadora de produtos brasileiros); crescimento dos preços das commodities. A conjuntura externa favorável proporcionou o crescimento das exportações, a reversão do déficit comercial e de transações correntes e o acúmulo de reservas internacionais que permitiram o pagamento antecipado de um montante da dívida externa com organismos internacionais (CARCANHOLO, 2010).

A partir de 2007/2008, a reversão da conjuntura internacional significou a volta dos problemas no balanço de pagamentos por duas razões: desaceleração do crescimento das exportações, em função da recessão mundial; e redução dos preços das 
commodities, tanto pela recessão como pela desvalorização do capital fictício aplicado na especulação dentro do mercado futuro de commodities. "Isso significa que a vulnerabilidade externa estrutural tende a se manifestar novamente na piora das contas externas" (CARCANHOLO, 2010, p. 126). O impacto da crise mundial sobre as contas externas foi agravado pela dinâmica da atração de investimentos externos de curto prazo e de natureza especulativa, necessários para o fechamento do balanço de pagamentos.

Quanto às relações do Brasil com o bloco África, essas parcerias foram e ainda são muito importantes, à medida que representam a diversificação dos mercados, maior autonomia brasileira nos assuntos de política externa, alianças que podem apresentar resultados ainda mais significativos no longo prazo e oportunidades vantajosas de investimentos diretos brasileiros no exterior.

Durante muitos anos, conforme salientou Vizentini (2007), a expansão imperialista, necessária à elevação do nível de vida das classes trabalhadoras metropolitanas, e a sua dinâmica, poucas vezes obedeciam a um cálculo de custo-benefício de curto prazo. Dada a concorrência entre os polos desenvolvidos, a não ocupação de um território relativamente pobre representava um espaço a ser posteriormente ocupado por outra potência, que talvez viesse a descobrir recursos importantes.

Analisando o interesse brasileiro pelos países africanos atualmente, entende-se que todas as estratégias adotadas também obedecem a uma lógica semelhante tanto para o estabelecimento de fluxos comerciais mais elevados, quanto para a implantação de empresas naqueles países. Por um lado, o Brasil tornou-se um grande consumidor de produtos africanos, gerador de divisas e que ajuda as empresas exportadoras manterem seus níveis de emprego e de renda. Muitas dessas empresas são filiais brasileiras, e sua produção compõe parte do produto nacional brasileiro. Ao mesmo tempo, com as rendas geradas na África, cria-se mercado consumidor para o produto interno do Brasil.

Em um mundo com constantes conflitos socioeconômicos e políticos, a estratégia de contemplar e harmonizar as diferenças é um elemento crucial no sistema internacional. Dizia List (1885 apud CHANG, 2004, p. 16) que "é um expediente muito comum e 
inteligente de quem chegou ao topo da magnitude chutar a escada pela qual subiu a fim de impedir os outros de fazerem o mesmo." Ao que parece, o Brasil pretende subir levando consigo os menos abastados. Não que essa solidariedade e cooperação brasileira se tratem de bondade desinteressada. Mesmo sendo um jogo político, não se cresce se os demais países com os quais são mantidas relações não crescerem também. A postura brasileira, chamada por alguns de 'em cima do muro', não gera conflitos diretos de interesses, exprime simpatia e conciliação política (principalmente entre os grupos econômicos brasileiros e as aspirações políticas do Brasil no cenário internacional).

\section{REFERÊNCIAS}

BAUMANN, R.; CANUTO, O.; GONÇALVES, R. Economia internacional: Teoria e experiência brasileira. Rio de Janeiro: Elsevier, 2004. $9^{a}$ reimpressão.

BCB. Banco Central do Brasil. Boletim/Balanço de Pagamentos de 2011. Dados sobre a evolução da taxa média de câmbio comercial R\$/US\$ do período 2002-2010. Acesso: <http://www. bcb.gov.br/Boletim/BP>

. Declarações do Capital Brasileiro no Exterior em 2006. Acesso: <http://www.bcb.gov.br/Declarações do CBE/2006>

. Declarações do Capital Brasileiro no Exterior em 2010. Acesso: <http://www.bcb.gov.br/Declarações do CBE/2010> CARCANHOLO, M. D. Inserção externa e vulnerabilidade da economia brasileira no governo Lula. In: Os anos Lula: contribuições para um balanço crítico 2003-2010. Rio de Janeiro: Garamond, 2010.

CHANG, H.-J. Chutando a escada: a estratégia do desenvolvimento com perspectiva histórica. São Paulo: UNESP, 2004.

FEIJÓ, R. L. C. Economia agrícola e desenvolvimento rural. Rio de Janeiro: LCT, 2011.

FIGUEIRA, A. R. Introdução à análise de política externa. Vol. 
1. São Paulo: Saraiva, 2011.

FILGUEIRAS, L.; GONÇALVES, R. A economia política do governo Lula. Rio de Janeiro: Contraponto, 2007.

et al. Modelo liberal-periférico e bloco de poder: política e dinâmica macroeconômica nos governos Lula. In: Os anos Lula: contribuições para um balanço crítico 2003-2010. Rio de Janeiro: Garamond, 2010.

GREMAUD, A. P.; VASCONCELLOS, M. A. S. de; TONETO JR., R. Economia brasileira contemporânea. $7^{a}$ ed. $6^{a}$ reimpr. São Paulo: Atlas, 2011.

IBGE, Instituto Brasileiro de Geografia e Estatística. Sistema de Contas Nacionais 2000 Anual.

IGLESIAS, R.; COSTA, K. P. da. Investimento estrangeiro direto na África. Centro de Estudos de Integração e Desenvolvimento. Novembro de 2011.

KON, A. Economia industrial. São Paulo: Nobel, 1999.

MAIA, J. de M. Economia internacional e comércio exterior. $14^{\mathrm{a}}$ ed. São Paulo: Atlas, 2011.

MINEIRO, A. S. Desenvolvimento e inserção externa: algumas considerações sobre o período 2003-2009 no Brasil. In: Os anos Lula: contribuições para um balanço crítico 2003-2010. Rio de Janeiro: Garamond, 2010.

MIRANDA, J.C.; TAVARES, M. da C. Brasil: estratégias da conglomeração. In: FIORI, J. L. (org.). Estados e moedas no desenvolvimento das nações. Petrópolis, RJ: Vozes, 1999.

MRE, Ministério das Relações Exteriores do Brasil. Acesso: <http:// www.mre.gov.br/>

Resumo executivo da política externa brasileira. 2011. Acesso: <http://www.mre.gov.br/>

RODRIGUES, S.; VARGAS, E.L. de; SILVA, F.P. da. Política externa brasileira: governos FHC e Lula práticas foco nas exportações e seus resultados. In: VI Encuentro Internacional de Investigadores de la Red Latinoamericana de Cooperación Universitaria. 
Viejos retos, nuevas propuestas: tecnología, cultura y sociedad en América Latina. Universidad de las Américas Puebla. 29 e 30 de outubro de 2009.

SECEX/MDIC. Secretaria de Comércio Exterior do Ministério do Desenvolvimento, da Indústria e do Comércio Exterior do Brasil. Dados do intercâmbio comercial brasileiro com alguns países. 2009. Acesso: <http://www.mdic.gov.br/secex>

Dados do intercâmbio comercial brasileiro, totais gerais. 2011. Acesso: <http://www.mdic.gov.br/secex>

Dados sobre exportações brasileiras totais por fator agregado. 2011. Acesso: <http://www.mdic.gov.br/secex>

Dados sobre intercâmbio comercial brasileiro com o bloco África, exclusive Oriente Médio. 2011. Acesso: <http:// www.mdic.gov.br/secex>

Dados sobre exportações brasileiras para o bloco África, exclusive Oriente Médio, por fator agregado. 2011. Acesso: <http://www.mdic.gov.br/secex>

SILVA, M. L. da. A inserção internacional das grandes empresas nacionais. In: LAPLANE, M.; COUTINHO, L.; HIRATUKA, C. (org.). Internacionalização e desenvolvimento da indústria no Brasil. São Paulo: Editora UNESP; Campinas, SP: Instituto de Economia da UNICAMP, 2003.

SOUZA, N. A. de. Economia brasileira contemporânea: de Getúlio à Lula. 2a ed. São Paulo: Atlas, 2008.

Economia internacional contemporânea: da depressão de 1929 ao colapso financeiro de 2008. Material do Portal Atlas. São Paulo: Atlas, 2009.

TAUTZ, C. et al. O BNDES e a reorganização do capitalismo brasileiro: um debate necessário. In: Os anos Lula: contribuições para um balanço crítico 2003-2010. Rio de Janeiro: Garamond, 2010.

VIZENTINI, P. F. As relações internacionais da Ásia e da África. Petrópolis, RJ: Vozes, 2007.

Relações internacionais do Brasil: de Vargas a Lula. $3^{\text {a }}$ ed. São Paulo: Editora Fundação Perseu Abramo, 2008. 